Athens Journal of History - Volume 8, Issue 2, April 2022 - Pages 99-108

\title{
The Lyceum in Twilight: Athens" "Second School" and its Struggle to Re-Invent Itself and Survive in the Last Years of the Roman Republic
}

\author{
By David P. Wick*
}

\begin{abstract}
After the Athenian crisis of the early 80's, which saw the ancient city held hostage between an Anatolian military expedition (whose leader at least claimed some intellectual credentials from Athenian schools including the Lyceum) and a renegade Roman with only the most cynical interest in heritage or culture, the schools of Athens - in particular the "peripatetic" school which dated back to Aristotle - faced challenges of identity, recruiting students, and in holding its own, perhaps too "peripatetic," faculty. In early post-classical and Hellenistic times the second and third generation Lyceum had been successful, even when it had lost intellectual "stars" like Theophrastus, and (worse) its original library, to rivals like Pergamum - but as the other schools attracted careerminded students from the west, Aristotle's foundation of a broad-minded liberal arts approach to learning in the Lyceum grove was in danger. The Lyceum seems actually to have failed for a time, or at least to have limped through the middle first century with faculty borrowed from the Akademe, in spite of a reputation for teaching practical politics which neither the Epicureans nor the Stoics could substitute for very well. Experts of the Aristotelian sort found either too-attractive employment in an Italy closer to the centers of power, or too strong a lure toward traveling consulting positions with neophyte Romans trying to learn the eastern Mediterranean "on their jobs." At its Athenian home, it moved a significant part of its teaching into the city and melded it into the ephebeia or "civic school" for young Athenian citizens (but in the new Athens, those included a more and more multi-cultural mix of foreign youth as the Republic's business class and students arrived in town). And then, it also attracted those in retirement from the turmoil of the disintegrating Republic, who valued the Lyceum more as a refuge than as a provider of power-skills for "players," the sort of thing the Akademe or the Epicurean 'Garden' did. The solution itself endangered Aristotle's idea for the school. As the Republic died, the "Peripatetic" school's greatest teachers were more often on the road with its "players" than home. What it kept at its home, though, it re-invested in the educational life of its own city. The Lyceum, like the Stoa, found its new Athenian home "downtown" in more ways than one, and faced challenges quite familiar both in modern "peripatetic" and in "career-direct" higher education.
\end{abstract}

Though this study is set in the last century of the Roman Republic, the story of the twilight struggle of Aristotle's school at Athens in the early Roman years is in many ways a very contemporary thing: an exploration of "small college" survival - the survival of Athens' "second school" after the most damaging crisis in the city's academic history.

I have explored the story of the crisis that triggered this in detail on previous

"Director, Arts, Humanities \& Education Division, ATINER \& Professor (Retired), Gordon College, USA. 
occasions, ${ }^{1}$ but the essentials are these. An Anatolian agent had in 88-87 attempted an anti-Roman coup in Athens, using credentials - true or false - as a student at the Lyceum and as a graduate of the Akademe, making out of them locally important intellectual capital. His name was Athenion. While paramilitary forces prepared for him in Pontus tried to engineer his takeover bid in the city, his rhetoric pushed buttons about the decline of the Athens from its classic years, the shrinking of its public life, the waning of the school he had attended.

"Let us not stand by inactive while the temples are shut, the gymnasia foul through disuse, the theater without the ecclesia, the jury-courts silent, and the Pnyx taken away from the people ... Let us not stand by inactive, men of Athens, whilst the sacred cry Iacchos is silenced, and the hallowed sanctuary of Castor and Pollux is closed, and the conference halls of the philosophers are voiceless." ${ }^{2}$

When his coup failed, his hired muscle took hostages from leading city families to keep the families themselves trapped within the walls. They dug in on the Acropolis. A Roman force removed them, but it was not made up of those Romans enchanted by the city's culture and schools that were becoming the city's lifeline. Instead, captive Athens fell to the eccentric, Epicurean-educated outlaw Sulla. Sulla succeeded at smashing the hostage takers, but in doing damaged the city callously, even rooted the trees out of the ancient groves of learning perhaps of what was left of the Lyceum, and certainly out of the Academe - and used them to build siege engines, in part just to show he was not mesmerized by the ancient cultural heritage around him, even if other Romans were. The "silence" in the schools was (for the Lyceum as we shall see) a little true, but the aftermath Athenion and Sulla left was in subtle ways far worse for smaller schools like Aristotles'. It set in motion an ancient first-century version of what we have, since the mid-20 $0^{\text {th }}$ Century, often called a "brain drain."

But damage to the Lyceum had begun earlier. Athens had survived the original war that brought the Romans to Greece - the war against Philip V of Macedon in the early 100's - as "walking wounded," but walking with a hopeful stride. Among the serious wounds it tried to ignore, though, were those to Aristotle's old school in the Lyceum grove. Roman defense against Philip's money-raising raids on an exhausted Greece arrived as asked, but what came to Athens was primarily naval and concentrated upon the excellent facilities in the Piraeus. ${ }^{3}$ Philip, after his war chieftain Nicanor had been bluffed back by the

1. Ref., e.g., D. P. Wick, "Students in the (Ancient) Streets, or Agent(s) Provocateur? The Liberal Arts Schools of Athens and the Hostage Crisis of 88," Athens Journal of History 6, no. 4 (2020): 299-312.

2. Athenaeus v, 212b. The translation is from W. S. Ferguson, Hellenistic Athens: A Historical Essay (London, 1911), 443.

3. Livy, XXXI, xiv, 3; and XXXI, xxii, 4 ff. 
ships, ${ }^{4}$ was forced to lead a spoiling raid through the Attic farm country himself. Though he was able to beat the Athenian hoplite force handily enough, he found the newly reinforced city impregnable. Frustrated, he moved round to its quiet southeastern outskirts and sacked its gymnasium (hitherto largely untouched by warfare), damaging the Cynics garden of Cynosarges and the Lyceum in the process. ${ }^{5}$ As he retreated, he attacked and mutilated statues and shrines in the Athenian suburbs and the country villages of Attica - if Athens wanted to play for Roman help using its spiritual auctoritas its symbolic heritage as trump cards, it could pay by seeing the symbols destroyed.

And so, the school limped through the new era down to the arrival of Sulla in the 80's, who was a Roman outlaw facing a return to Rome and an attempted coup of his own. He needed both intellectual capital and perhaps some strategic help. His victory against Aristion and Archelaus (Athenion's replacements) at Athens he hoped would read as a victory over Mithridates and his Anatolian provocateur insurgents, defense of an innocent city. He needed to acquire some captive expertise and the fashionable cachet, just as the victories of Aemilius Paullus had allowed him to confiscate his own following of Greek intellectuals almost a century earlier. There was no Polybius to bring to Rome this time, but Sulla's officer Ateius, according to Plutarch the first over the wall in the taking of Athens, caught himself the grammarian Philologus and carried him, as Sulla's army orchestrated chaos after the Battle of the Colline Gate and managed his coup, back to a distinguished career at Rome. ${ }^{6}$

Such "exports" as that did Athens as a city no good at all, of course. Political refugees from the post-Sullan war torn Greece filled the small and shifting market for elite teachers in Italy rather than advertising the home campus of Aristotle. In a study on the Akademe intended to follow this one (and presented in early form at ATINER) I noted how Philo of Larissa fled his post as head of the Academy when the onslaught of Mithridatic propaganda (and perhaps the early machinations of the Peripatetic political adventurer Athenion) began to seem menacing. In Rome, Philo attracted both followers and controversy (see below). Both are likely as not to have attracted a few more students to the Athenian schools, but neither Philo nor his antagonist Antiochus of Ascalon returned to teach in Athens during the next years. Philo was soon dead, and Antiochus found it convenient to disappear into the newly-Roman East as advisor to Lucullus. Aristotelians like Philologus stayed in Italy for the same reasons.

And yet, all the trouble could have helped a "second school" like the Lyceum. After all, it was "collateral damage" caused by the cloud of suspicion and notoriety

4. Polybius xvi, 27; Livy XXXI, xvi, 2 (where the general is called Philocles).

5. Diodorus, xxviii, 7.

6. Suetonius, De Grammaticis, 10; Varro, De Lingua Latinae vii, 10; J. P. V. D. Balsdon, Romans and Aliens (Chapel Hill, 1979), 57; Rawson, Intellectual Life in the Late Republic (London, 2002), 124. 
hanging over the Akademe after the duel between Mithridates and Sulla. It was heightened by the behavior of Sulla himself in Italy over the next few years -Sulla advertised his roots in the Epicurean school. Athenion, the Mithridatic agent who had begun this "hostage crisis" that Athens barely survived at the beginning of the 80 's, had used some form of credential from study at the Aristotelian and Platonic schools as political ammunition, but he had left studies at the Lyceum to finish at the Academe. He had, into the bargain, tried to paint a picture of a damaged or dying academic world, as he also tried to depict a political Athens strangled by pro-Roman business interests.

So, could the Mithridatic crisis in the Athens of the 80's help the Lyceum? If the heaviest damage was to the reputation of the Platonic academe, that school was still so embedded in the Mediterranean intellectual landscape that it was very resilient. ${ }^{7}$ It remained not only economically viable, but by far the most famous and attractive of Athenian schools. The Lyceum could not prevent it from continuing to skim the cream of a momentarily shocked and suspicious clientele especially in the Mediterranean to the west of Greece. How was the "second school" of Athens during this era to survive, to create an intellectual persona that could attract its fair share of critical new (western) students? Where were its wealthy or powerful alumni to come from in the new era?

For an intellectual mascot, the Akademe had Plato (however far it now strayed from his teachings). The Aristotelian approach to human culture and the universe was still worth something, though. The Lyceum aimed, in the popular perception at least, at collecting and understanding real-world data about life; a rival for those Epicureans bent on "engineering" data toward concrete goals; a rival for those Stoics who claimed to achieve an inner balance and spiritual perspective on life. It was not quite as famous, or as fashionable, but the age between Sulla and Caesar gave it a moment to shine.

\section{The Lyceum, Not Quite Silent}

The most significant place to start, then, would be (for the student culture of Athens) with the fact that Athenian ephebic inscriptions of the period after Sulla's siege no longer mention any lectures continuing at either the Academy or the Lyceum. ${ }^{8}$ Of the schools Athens supported, the Lyceum had radical challenges to face.

Part of its particular trouble lay rooted in a weakness (intended as a strength)

7. See Wick, "Stoics and Epicureans for the 'Modern Market': How Athenian Educators Re-Tooled the Old City's 'Modernist Schools' for Republican Rome," Athens Journal of History 3, no. 4 (2017): 265-274, and a coming study of the surviving Akademe in this same vein.

8. J. Glucker, Antiochus and the Late Academy (Göttingen, 1978), ch. 1; Rawson, op. cit., 11. 
as old as Aristotle himself - the practice of encouraging traveling research, the "overseas semester" that produced so much of what filled the Aristotelian essays as scholar after scholar returned to the school and enriched it with what they had studied first-hand in foreign places. As often as not they stayed where they studied, and this era only made that likelier. Aristotle had, after all, not only studied "away" while running the new Lyceum, but had left it for an extended stay with the young Alexander in Macedon. His successor Theophrastus, after considerable success in Athens, had taken a more lucrative offer from Pergamum, and actually absconded with the school's library on his departure. ${ }^{9}$

Scholars suspect that the succession of teachers and administrators may actually have lapsed at Aristotle's old school after the war with Philip. ${ }^{10}$ Aside from the famous Critolaus of the second century B.C., we have names of probable scholarchs or lead scholars at the Lyceum who include Diodorus of Tyre (he likely taught the father of the political predator Athenion), an Erymneus (just a name), the rather uncertain Andronicus of Rhodes and Boethius of Sidon, and finally the better-known Cratippus of Pergamum who Cicero speaks of during is later years. ${ }^{11}$ But Cratippus (a story I followed in my article on the Platonic Akademe) was actually a student of the famous, revionist, platonist Antiochus of Ascalon, and then briefly of his duller brother Aristus, and possibly - given his practical tendencies - even of the skeptical Philo before them. He did not even pretend to be Aristotelian when he taught at the Lyceum; it simply had a teaching position open. The Peripatetics of Aristotle's old school may have espoused him as a sort of stop-gap. He put students in seats.

If Cicero's Athens really had a Lyceum without Aristotelians, that might in turn add some color to a list in Clement of Alexandria, which seems to imply that Diodorus of Tyre was the last Peripatetic scholarch, and that Erymneus was

9. J. P. Lynch, Aristotle's School: a Study of Greek Educational Institution (Berkeley, 1972). The library seems to have gone with either Theophrastus or his entourage of students to Pergamum in Asia Minor and thence, via the brokerage of the bookdealer/adventurer/ naval brigand Apellicon of Teos, onto the Athenian 'used' market, thence into Sulla's hands, and finally to Italy. See Rawson, Intellectual Life in the Late Republic, 2002, 40, and related discussions). A really good library, one suspects, would in any case have been far more critical for the serious continuation of Aristotelian studies than Platonic or Epicurean, ref. points made in this author's presentation "Scholar, Smuggler, Mercenary, Thief - A Brief Introduction to the Strange History of the Library of Pergamon, and the Stranger Men Who Built and Broke It," In ATINER Conference on the Arts \& Humanities, January 2021 (a revision presented at the conference on History, June 21)...

10. Lynch, Aristotle's School: A Study of Greek Educational Institution, 1972, 290-291.

11. J.-L. Ferrary, Philhellénisme et Impérialisme: Aspects Idéologiques de la Conquête Romaine du Monde Hellénistique, de la Seconde Guerre de Macédoine à la Guerre Contre Mithridate (Rome, 1988), 465; Cf. Lynch, Aristotle's School: A Study of Greek Educational Institution, 1972, 203-205. 
merely one of his students. ${ }^{12}$ The Athenian dialogue in Cicero's de Finibus (set in 79) places M. Pupius Piso in the position of defending the honor of Aristotle and Theophrastus; there sadly being no defender available from among Athenian teachers at all, though Antiochus of Ascalon is able to in the piece to appear for the Academics. ${ }^{13}$ In it Piso also lists a "roll" of Peripatetic leaders, which ends with Diodorus. Such a gap in its turn casts a light backward onto the "silence" of the schools about which Athenion complained in 88, since Diodorus is likely to have been dead by 90 B.C.. ${ }^{14}$

Antiochus of Ascalon, if Glucker was correct, attempted when Diodorus died, and Philo of Larissa fled looking for consulting fees on the road, to strengthen his own fledgling school (he called it the "Old Academy") by claiming in it to revive in it both the true precepts of the early Academics and Peripatetics. Yes, there were two competing Platonic schools in these years, both rather practical in career terms, neither very orthodox as Plato would have seen them, and the newest one claimed it had replaced the Lyceum. So, the Cratippus of Pergamum I mentioned earlier, tried to attract students claiming he was less "stoic" that then city's current "star" academic, Aristus; he said nothing about being Aristotelian, just that he was a more practical option for the career-minded student than one could get at the Akademe. ${ }^{15}$ Professorial talent was so thin on the ground that one could claim an "old school" credential by representing any motley "footprint" of ancestral Athenian teachers or traditions one wished.

At any rate, Cicero came through in the 70's and heard no one teaching a regular course at the Lyceum, though the young Lucius Cicero seems to have thought that there might be Peripatetic lectures somewhere in town. He was anxious to hear about the legendary verbal fireworks of Carneades. ${ }^{16}$ This disappointment must have been severe for many young Romans: the Aristotelian school would have been the one place in Athens where one could hope to get the real, practical, scientific stuff of civil success and governmental skill. If two Peripatetic students had been involved in the tragic firestorm of the "88" revolution (as everyone seems at least to have believed), ${ }^{17}$ it was only because Aristotle's school was supposed to teach practicing political theory. However their parents may have felt, it remains hard to imagine young Romans cut of the

12. Clement of Alexandria, Stromateis I (XIV), 63-64.

13. M. T. Cicero, De Finibus, v, 13-14.

14. Glucker, Antiochus and the Late Academy, 1978, 15-21; D. Sedley, "The End of the Academy," Phronesis (1981): 70-71; Ferrary, p. 469.

15. Glucker, Antiochus, pp. 119-120; Ferrary, Philhellénisme et Impérialisme: Aspects Idéologiques de la Conquête Romaine du Monde Hellénistique, de la Seconde Guerre de Macédoine à la Guerre Contre Mithridate, 1988, 469, n. 115.

16. Cicero, De Finibus, v, 6.

17. Ferrary, Philhellénisme et Impérialisme: Aspects Idéologiques de la Conquête Romaine du Monde Hellénistique, de la Seconde Guerre de Macédoine à la Guerre Contre Mithridate, 1988, 472-473. 
cloth of Catiline or Caelius Rufus being put off by tales about the downfall of Athenion.

By comparison, the Epicurean schools were full of theoretical "logical positivists" or power strategists (however good the food was), the typical image a caricature of wise-clever intellectuals who cocked a skeptical eyebrow and debunked social myths, who would tell you for a fee that a proper understanding of your component atoms would cure your anxieties. These were what the English a century ago called "Balliol men;" if young Romans of the late Republic were going to be taught by magistri Graeculi they didn't want clever theorists about science and harmony with nature and a love for human culture, they wanted men who knew the inside of "Whitehall" or "the Hague" - the way "insider meetings" in a government worked, how to manipulate voters during volatile elections, how to skew public trials or scandals so they spun the right way - all interests we find very familiar in the $21^{\text {st }}$ century. In modern terms, the "liberal arts" and the "examined life" were passé; you wanted your children to learn how to negotiate the hard way with creditors or investors, or ministers from the EU.

But, this didn't feel to clients buying schooling at the Lyceum as though it were a betrayal of an ancient heritage. Aristotle, after all, hadn't talked about ataraxia, the trendy new Greek word for a life free of anxiety, he had talked about government, and now there was no one in his place now doing what he had done. Cratippus, who seems to have done some "filling in" in the 40 's, was ready on the slightest suggestion of Cicero to pack up and go on an Asian tour with Cicero's son if there were a little real money forthcoming. ${ }^{18}$

Thus the "silence in the school" the political predator Athenion rose a cry about need not have been due to any cessation of public teaching, nor to any putative Roman intervention in the Attic system of education, nor need we suppose with Badian that the Peripatetics were somehow "at odds with the Athenian establishment." 19

Athens was after 89/88 simply left with a decaying and second-rate Aristotelian school, in the wreckage of which we can glimpse only a few uncertain names and a momentary flash of dangerous political adventure. Glucker supposes the decline to have arisen when the Asian college at Pergamum, which had long boasted itself as the premier Aristotelian school, source a better class of Peripatetic scholars, sank under the wave of Roman exploitation. ${ }^{20}$

Aristotelian studies would have their renaissance not in Athens but in Italy. ${ }^{21}$ Andronicus of Rhodes, far from growing into the post of scholarch of the Lyceum, was already or would soon headed for Italy himself, where the Peripatetic library

18. Cicero, Epistulae ad Familiares, XII, xvi, 2.

19. E. Badian, "Rome, Athens, and Mithridates," (Gorgias Press, 2016), 513.

20. Glucker, Antiochus, 1978, 373-379.

21. Rawson, Intellectual Life in the Late Republic, 2002, 291. 
of Pergamum had also gone. For the rest of his life, he would undertake with Tyrannio the definitive edition of Aristotle's works. ${ }^{22}$

To be sure, Aristotle's old school at Athens was not yet quite dead, like the Academe and the others, it became one of the few easily available weapons Athens retained for its struggle to find an important place in the Roman world. Tourism could be turned into an educational draw, and it was. Athenian civic education (the ephebeia) was revamped to regularize the status of foreign students alongside the native children. The Lyceum was stirred into the mix of city attractions. Students of the state-run civic school, the ephebeia included Romans now right alongside old-family Athenians. They attended occasional lectures in the Ptolemaeum by principal teachers of (at least) the Lyceum and Plato's school. ${ }^{23}$ An inscription honors the class of 123/122 for listening to "the lectures of Zenodotus at the Ptolemaeum and the Lyceum and also all the other philosophers in the Lyceum and the Academy throughout the year." ${ }^{24}$ The corps of ephebes were in turn required to donate each year some one hundred volumes to its library. ${ }^{25}$ The foreigners among them could now gain for Athenian citizenship, if they wished it just by finishing a course of study. ${ }^{26}$ But it was the Lyceum name lending its 'cachet' to an educational business downtown. The old grove lay in the shadows.

The ageing buildings of the classical Athenian democracy looked down from the heights above the Lyceum grove like the ghosts of a purer era. Whatever violence or deceit they might have seen in their day, they had seen not just brilliance, but a brilliance in which competing, contesting and mutating points of view could be melded into an on-going cultural dialogue.

The shade of this across the crowded, intimate landscape of schools and lecturers, statues and dedications told a story. Perhaps in reaction to what Sulla had done, the Romans in their better moments would shade the city of Athens and schools from the crumbling Hellenistic world and their own convulsing Republic. They often returned to Athens, especially to old schools like the Lyceum, when their own power games disintegrated. Whether from nostalgia like Cicero's, or a desire like that of Brutus after Caesar's assassination simply to disappear into a

22. Strabo, XIII, C609; XII, C548; XVI C757; Cf. Cicero expecting to find very technical works on Aristotle in the library of Lucullus, Ad Att. IV, x, 1; De Finibus iii, 10; and v, 12.

23. Inscriptiones Graecae (vol. I2), 1006.19.

24. Inscriptiones Graecae, (vol. I2), 1006.19. The "Ptolomaeum" was the site of the Athenian ephebeia or "civic high school" courses, but the lectures were open to visitors (especially Mediterranean or especially Roman business families interested in settling in or trading with Athens, whose children could gain Athenian "double citizenship" if they passed the courses).

25. Ibid; Cf. Ferguson, Hellenistic Athens: A Historical Essay, 1911, 416; Rawson, Intellectual Life in the Late Republic, 2002, 12.

26. J. K. Davies, "Athenian Citizenship: The Descent Group and the Alternatives," Classical Journal 73 (1975): 119; Cf. M. J. Osborne, Naturalization in Athens (Brussels, 1982), 205. 
lost, calm world imagined from student days, Roman after Roman came back, and for a time, the aura of the old schools sheltered them.

What this could not do, of course, was save the schools as schools. Those that survived adapted to the new world of power politics and speech media. The broad-minded, tolerant, multi-faceted wisdom - the "liberal arts perspective" if you will - that Aristotle had intended would distinguish his school from the Academy, that allowed it more societal innovation than the Stoa, that kept its investigations more integrated with culture and wisdom than the Scientists at the "Garden," was difficult (as it is in our own day) to articulate to a culture of students who hoped to turn tools to their own agendas overnight. Faced with that, the Lyceum seems to have been unable even to hold onto its faculty. Consulting positions, attachments to the players of power were always a danger to a school with the Aristotelian approach. In eras like the late Roman Republic (and in some ways in ours) they formed a weakening solvent that left the school of Aristotle desperately challenged, and produced students who could compete in the dangerous player politics of the new world (one so like ours) but very few of whom could step back from it, diagnose, and truly try to cure it.

\section{Bibliography}

Athenaeus. Deipnosophistae (See notes or for further reading search on "Akademe," "Lyceum," "Peripatetic" or by scholar name).

Badian, E. Rome, Athens, and Mithridates. Gorgias Press, 2016.

Balsdon, J. P. V. D. Romans and Aliens. Chapel Hill, 1979.

Cicero, M. T. De Finibus Bonorum et Malorum. (On the Ends of Good and Evil.) . Epistulae ad Familiares. (Letters to Friends.)

Clement of Alexandria. Stromateis I. XIV.

Davies, J. K. "Athenian Citizenship: The Descent Group and the Alternatives." Classical Journal 73 (1975).

Diodorus Siculus. Universal History. XXVIII.

Ferguson, W. S. Hellenistic Athens: A Historical Essay. London, 1911.

Ferrary, J.-L. Philhellénisme et Impérialisme: Aspects Idéologiques de la Conquête Romaine du Monde Hellénistique, de la Seconde Guerre de Macédoine à la Guerre Contre Mithridate. (Philhellenism and Imperialism: Ideological Aspects of the Roman Conquest of the Hellenistic World, from the Second Macedonian War to the War Against Mithridates). Rome, 1988.

Glucker, J. Antiochus. Göttingen, 1978.

Livy. History of Rome. bk XXXI.

Lynch, J. P. Aristotle's School: A Study of Greek Educational Institution. Berkeley, 1972.

Osborne, M. J. Naturalization in Athens. 2 Volumes. Brussels, 1982.

Polybius. History. XVI.

Rawson, E. Intellectual Life in the Late Republic. London, 2002.

Sedley, D. "The End of the Academy." Phronesis (1981).

Strabo. Geography.

Suetonius. De Grammaticis. (On Grammar.) 
Varro. De Lingua Latinae. (On the Latin Language.) VII.

Wick, D. P. “Stoics and Epicureans for the 'Modern Market': How Athenian Educators ReTooled the Old City's 'Modernist Schools' for Republican Rome." Athens Journal of History 3, no. 4 (2017): 265-274.

. "Students in the (Ancient) Streets, or Agent(s) Provocateur? The Liberal Arts Schools of Athens and the Hostage Crisis of 88." Athens Journal of History 6, no. 4 (2020): 299312 . 